\title{
Cell-wall proteinases PrtS and PrtB have a different role in Streptococcus thermophilus/Lactobacillus bulgaricus mixed cultures in milk
}

\author{
P. Courtin, V. Monnet and F. Rul
} Author for correspondence: F. Rul. Tel: +331346521 48. Fax: +3313465 2163.
e-mail: rul@jouy.inra.fr

Unité de Biochimie et Structure des Protéines, INRA, 78352 Jouy-en-Josas Cedex, France

\begin{abstract}
The manufacture of yoghurt relies on the simultaneous utilization of two starters: Streptococcus thermophilus and Lactobacillus delbrueckii subsp. bulgaricus (Lb. bulgaricus). A protocooperation usually takes place between the two species, which often results in enhanced milk acidification and aroma formation compared to pure cultures. Cell-wall proteinases of Lactococcus lactis and lactobacilli have been shown to be essential to growth in milk in pure cultures. In this study, the role of proteinases PrtS from S. thermophilus and PrtB from Lb. bulgaricus in bacterial growth in milk was evaluated; a negative mutant for the prtS gene of $S$. thermophilus CNRZ 385 was constructed for this purpose. Pure cultures of S. thermophilus CNRZ 385 and its PrtS-negative mutant were made in milk as well as mixed cultures of $S$. thermophilus and Lb. bulgaricus: S. thermophilus CNRZ 385 or its PrtS-negative mutant was associated with several strains of $\mathbf{L b}$. bulgaricus, including a PrtBnegative strain. The $\mathrm{pH}$ and growth of bacterial populations of the resulting mixed cultures were followed, and the Lactobacillus strain was found to influence both the extent of the benefit of $L b$. bulgaricus/S. thermophilus association on milk acidification and the magnitude of $S$. thermophilus population dominance at the end of fermentation. In all mixed cultures, the sequential growth of $S$. thermophilus then of $\mathbf{L b}$. bulgarius and finally of both bacteria was observed. Although proteinase PrtS was essential to $S$. thermophilus growth in milk in pure culture, it had no effect on bacterial growth and thus on the final pH of mixed cultures in the presence of PrtB. In contrast, proteinase PrtB was necessary for the growth of $S$. thermophilus, and its absence resulted in a higher final pH. From these results, a model of growth of both bacteria in mixed cultures in milk is proposed.
\end{abstract}

Keywords: bacterial growth, milk fermentation, thermophilic bacteria

\section{INTRODUCTION}

Streptococcus thermophilus is a thermophilic lactic acid bacterium (LAB), widely used as a starter to produce fermented dairy products. It is generally used in association with other micro-organisms, in particular with Lactobacillus delbrueckii subsp. bulgaricus (Lb. bulgaricus) for the manufacture of yoghurt. For this application, the fast-growing capacity of these bacteria in milk is crucial to enable intense and rapid acidification

Abbreviations: FSDA, Fast Slow Difference Agar; LAB, lactic acid bacterium/bacteria. of milk. LAB are fastidious micro-organisms, which have in particular several amino acid auxotrophies. Most S. thermophilus strains are stimulated by the supply of two to five amino acids (Bracquart \& Lorient, 1977; Letort \& Juillard, 2001; Shankar \& Davies, 1977), whereas lactobacilli require between three and 14 amino acids (Hebert et al., 2000; Ledesma et al., 1977; Morishita et al., 1981). The optimal growth of LAB in milk thus depends on their proteolytic system, which hydrolyses milk caseins into peptides and amino acids (Thomas \& Mills, 1981). The cell-wall proteinases of $\mathrm{LAB}$ are of major importance in this process, as they are responsible for the first step of casein breakdown. They 
belong to the same multi-domain proteinase family and show significant homologies, even though differences in specificity, bacterial anchor and domain organization have been described (Fernandez-Espla et al., 2000; Siezen, 1999). The cell-wall proteinase of Lactococcus lactis (PrtP), which is very frequent in this species, has been extensively studied. In milk, Lc. lactis PrtP-negative strains only reach $10 \%$ of the cell densities observed with PrtP-positive strains (Thomas \& Mills, 1981). In S. thermophilus, the presence of a cell-wall proteinase, PrtS, recently characterized, is less common than in $L c$. lactis. In this species, high cell-wall proteinase activities are associated with high milk-acidifying capacities (Shahbal et al., 1991). In Lb. bulgaricus, the cell-wall proteinase, PrtB, is also essential for optimal growth in milk; a proteinase-negative strain reaches only $22 \%$ of the final biomass of a proteinase-positive strain when grown in milk (Gilbert et al., 1997).

In yoghurt, S. thermophilus and Lb. bulgaricus are grown in association, which often results in a positive interaction. This relationship, called protocooperation, has a beneficial effect on growth of both species and on acid and aroma production. S. thermophilus indeed produces pyruvic acid, formic acid and $\mathrm{CO}_{2}$ (for reviews, see Tamine \& Robinson, 1999; Zourari et al., 1992), which stimulate the growth of Lb. bulgaricus. In turn, Lb. bulgaricus produces peptides and amino acids that stimulate $S$. thermophilus growth (Accolas et al., 1971; Bautista et al., 1966; Higashio et al., 1977; Pette \& Lolkema, 1950b; Radke-Mitchell \& Sandine, 1984), which correlates with a lower proteolytic capacity of $S$. thermophilus compared to Lb. bulgaricus (Hamdy et al., 1955; Hickey et al., 1983; Rajagopal \& Sandine, 1990; Shankar \& Davies, 1978).

In the present study, we wished to determine the role of the cell-wall proteinases PrtS from S. thermophilus and PrtB from Lb. bulgaricus in bacterial growth in milk. We therefore constructed a negative mutant for the cell-wall proteinase gene (prtS gene) of S. thermophilus CNRZ 385 , which was recently sequenced and characterized in our laboratory (Fernandez-Espla et al., 2000). The latter mutant was used to study the role of PrtS on the growth of $S$. thermophilus in pure culture in milk. We also took advantage of the availability of a PrtB-negative mutant of Lb. bulgaricus (Gilbert et al., 1997) to evaluate the role of cell-wall proteinases PrtS and PrtB on growth and thus on acidification in S. thermophilus/Lb. bulgaricus mixed cultures.

\section{METHODS}

Plasmids, bacterial strains, culture conditions and bacterial enumeration. The bacterial strains and plasmids used for this study are presented in Table 1.

Strains of $S$. thermophilus and Lb. bulgaricus were grown in three different media: reconstituted skim milk (Nilac Low Heat Milk powder, NIZO) heated for $10 \mathrm{~min}$ at $95^{\circ} \mathrm{C}$, supplemented with yeast extract $\left(3 \mathrm{~g} \mathrm{l}^{-1}\right.$; Difco) when required, M17 medium (Terzaghi \& Sandine, 1975) supplemented with $20 \mathrm{~g}$ lactose $\mathrm{l}^{-1}$, and MRS medium (De Man et al., 1960) supplemented with 20 lactose $\mathrm{g}^{-1}$ and acidified at
$\mathrm{pH} 5 \cdot 2$, supplemented with streptomycin (Sigma) $\left(2 \mathrm{mg} \mathrm{ml}^{-1}\right)$ when required. The Escherichia coli strain was grown at $37^{\circ} \mathrm{C}$ on Luria-Bertani (Difco) medium (Sambrook et al., 1989) with shaking, in the presence of erythromycin (Ery) $\left(150 \mu \mathrm{g} \mathrm{ml}^{-1}\right)$ when required.

Stock cultures of each strain of $S$. thermophilus and $L b$. bulgaricus were prepared after growth at $42^{\circ} \mathrm{C}$ on skim milk, supplemented with yeast extract for proteinase-negative strains, from overnight skim milk cultures, supplemented with yeast extract when required. The $\mathrm{pH}$ was then measured, and bacterial numbers were estimated by plating, with an automatic spiral plater (AES Laboratory), appropriate dilutions of the culture on agar medium: M17Lac was used for specific enumeration of $S$. thermophilus cells, and MRSLac $\mathrm{pH} 5 \cdot 2$, supplemented with streptomycin when required, for specific enumeration of $L b$. bulgaricus cells. For S. thermophilus strains and before dilution, chains of cells were disrupted for $30 \mathrm{~s}$ in a mechanical blender (Turax X620, Labo-Moderne). After $48 \mathrm{~h}$ incubation at $42{ }^{\circ} \mathrm{C}$ in anaerobic jars (Anaerocult A, Merck), cells were enumerated with the EC1 colony counter software (AES Laboratory). At the end of culture, bacteria were directly frozen in liquid nitrogen and kept at $-80^{\circ} \mathrm{C}$.

Growth rates of $S$. thermophilus 385 and 385-PrtS strains were determined in M17 at $42{ }^{\circ} \mathrm{C}$ using a Microbiology Reader Bioscreen C (Labsystems) in 100-well, sterile, covered microplates. Each well, containing $200 \mu \mathrm{l}$ M17Lac, was inoculated at $1 \%$ with overnight M17Lac cultures of $S$. thermophilus and covered with one drop of paraffin oil. The optical density was measured at $600 \mathrm{~nm}$ every $20 \mathrm{~min}$, after gentle shaking. The apparent growth rate $\left(\mu_{\max }\right)$ was defined as the maximum slope of semi-logarithmic representation of growth curves, assessed by optical density measurements.

Mixed cultures of $S$. thermophilus and $L b$. bulgaricus strains were performed at $42^{\circ} \mathrm{C}$ by inoculating skim milk with $5 \times 10^{6}$ c.f.u. $\mathrm{ml}^{-1}$ of stock cultures of each strain. For proteinasenegative strains, cells from stock culture were washed three times in $50 \mathrm{mM}$ Tris buffer ( $\mathrm{pH} 7$ ) before inoculation to avoid peptides and/or amino acids being supplied in the mixed culture. Every $20 \mathrm{~min}$, the $\mathrm{pH}$ of the culture was measured, and bacteria were enumerated as described above. Total bacterial populations were estimated by addition of data from enumerations of each bacterial species on specific medium to the others, as indicated above.

Proteinase assay. The PrtS proteinase phenotype of $S$. thermophilus strains was determined on bacterial colonies in two ways. First, bacteria were grown on FSDA medium (Fast Slow Difference Agar) (Huggins \& Sandine, 1984). This milkbased agar medium made it possible to differentiate bacteria exhibiting slow or limited growth in milk from those exhibiting rapid growth; in particular, bacteria possessing a cell-wall proteinase activity appeared as white, opaque, rounded colonies, whereas proteinase-negative colonies were small, flat and translucent. Second, bacteria from an overnight skim milk culture were diluted and plated on agar skim milk plates (cell culture dishes, $35 \mathrm{~mm}$ in diameter). After $24-48 \mathrm{~h}$ incubation at $42{ }^{\circ} \mathrm{C}$ in anaerobic jars, colonies were covered by a solution containing Tris buffer $(50 \mathrm{mM}, \mathrm{pH} 7)$, a chromogenic substrate of proteinase PrtS (Suc-Ala-Ala-ProPhe- $\beta \mathrm{NA}, 10 \mathrm{mg} \mathrm{ml}^{-1}$; Novabiochem), $10 \mathrm{mg} \mathrm{ml}^{-1}$ Fast-Garnet (GBC, Sigma) and 10-50 $\mathrm{mM} \mathrm{CaCl}_{2}$. PrtS-positive clones appeared as red colonies, whereas PrtS-negative clones remained white.

Proteinase activity was measured on cellular suspensions using $\left[{ }^{14} \mathrm{C}\right]$ casein as the substrate according to the method of Monnet et al. (1987), modified as follows. Cell suspensions 
Table 1. Bacterial strains and plasmids

\begin{tabular}{|c|c|c|}
\hline Strain or plasmid & Relevant properties & Source or reference \\
\hline \multicolumn{3}{|l|}{ Strains } \\
\hline S. thermophilus CNRZ 302 & Protease-negative $\left(\mathrm{PrtS}^{-}\right)$ & Shahbal et al. (1991) \\
\hline S. thermophilus CNRZ 385 & Protease-positive $\left(\mathrm{PrtS}^{+}\right)$ & Shahbal et al. (1991) \\
\hline S. thermophilus CNRZ 703 & Protease-positive $\left(\mathrm{PrtS}^{+}\right)$ & Shahbal et al. (1991) \\
\hline S. thermophilus CNRZ 385-PrtS & Protease-negative $\left(\mathrm{PrtS}^{-}\right)$mutant of CNRZ 385 & This work \\
\hline Lb. bulgaricus CNRZ 397 & Protease-positive $\left(\mathrm{PrtB}^{+}\right)$ & Laloi et al. (1991) \\
\hline Lb. bulgaricus $1159=397-\operatorname{PrtB}$ & Protease-negative $\left(\mathrm{PrtB}^{-}\right)$mutant of CNRZ 397 & Gilbert et al. (1997) \\
\hline Lb. bulgaricus 1038 & $\begin{array}{l}\text { Protease-positive }\left(\mathrm{PrtB}^{+}\right) \text {, streptomycin-resistant mutant of } \\
\text { CNRZ } 208 \text { (ATCC11842) }\end{array}$ & $\begin{array}{l}\text { M. Van de Guchte (personal } \\
\text { communication) }\end{array}$ \\
\hline Lc. lactis MG1363 & Plasmid-free derivative of wild-type strain NCDO712 & Gasson (1983) \\
\hline E. coli $\mathrm{TOP} 10$ & recA1 & Invitrogen \\
\hline \multicolumn{3}{|l|}{ Plasmids } \\
\hline pCR-XL-TOPO & TOPO-Cloning site; $\mathrm{Kan}^{\mathrm{R}}$ & Invitrogen \\
\hline pCR-XL-TOPO- $\Delta p r t S-1$ & $3.776 \mathrm{~kb}$ fragment prtS in pCR-XL-TOPO; $\mathrm{Kan}^{\mathrm{R}}$ & This work \\
\hline pCR-XL-TOPO- $\Delta p r t S-2$ & $\begin{array}{l}\text { Blunt-ended and circularized } 5 \cdot 4 \mathrm{~kb} B s g \mathrm{I} \text { fragment of pCR-XL- } \\
\text { TOPO- } \Delta p r t S-1 ; \mathrm{Kan}^{\mathrm{R}}\end{array}$ & This work \\
\hline pG + host 9 & Ery $^{\mathrm{R}}$ & Maguin et al. (1996) \\
\hline $\mathrm{pG}+\mathrm{h} 9:: \Delta p r t S$ & $\begin{array}{l}2 \cdot 078 \mathrm{~kb} \text { NotI and SpeI fragment of pCR-XL-TOPO- } \Delta p r t S-2 \\
\text { ligated to pG + host } 9 ; \text { Ery }^{\mathrm{R}}\end{array}$ & This work \\
\hline
\end{tabular}

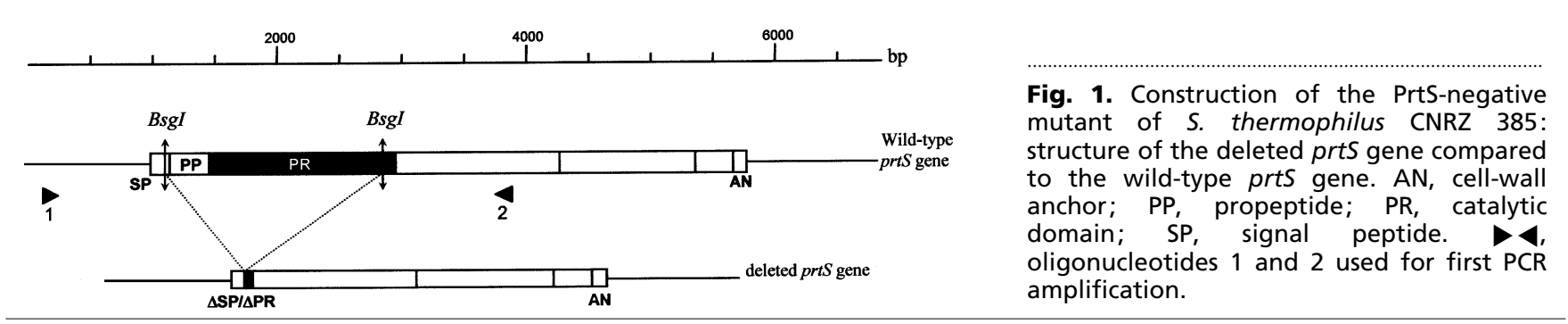

were prepared from $4 \mathrm{ml}$ overnight M17 cultures; cells were recovered by centrifugation $\left(20 \mathrm{~min}, 8000 \mathrm{~g}, 4^{\circ} \mathrm{C}\right)$ and washed three times in Tris buffer $(50 \mathrm{mM}, \mathrm{pH} 7)$. The last pellet was suspended in $150 \mu \mathrm{l}$ Bistris buffer $(50 \mathrm{mM}, \mathrm{pH} 6.5)$ containing $10 \mathrm{mM} \mathrm{CaCl}$. Fifty microlitres of cell suspension was incubated with $50 \mu \mathrm{l}$ of ${ }^{14} \mathrm{C}$ casein solution $(0 \cdot 1 \%)$ at $37{ }^{\circ} \mathrm{C}$ for 15, 60 and $120 \mathrm{~min}$. Enzyme reactions were stopped by the addition of $100 \mu \mathrm{l}$ TCA $(12 \%)$, left for $30 \mathrm{~min}$ at room temperature and centrifuged for $2 \mathrm{~min}$ at $10000 \mathrm{~g}$, and the radioactivity was then measured in the supernatants. Protease activity corresponded to the percentage of casein hydrolysis in $10 \mathrm{~min}$.

\section{DNA manipulations and sequencing}

Total DNA preparation. Total DNA of S. thermophilus CNRZ 385 was prepared as described by Pospiech \& Neumann (1995).

Preparation of electrocompetent cells of $S$. thermophilus and $L C$. lactis. Electrocompetent cells of S. thermophilus CNRZ 385 and Lc. lactis MG1363 were prepared according to the method of Holo \& Nes (1989), modified as follows. From an overnight culture in M17Lac, a culture was performed at $37^{\circ} \mathrm{C}(S$. thermophilus) or at $30^{\circ} \mathrm{C}$ ( Lc. lactis) by $1 \%$ inoculation of M17Lac containing DL-Thr $(100 \mathrm{mM})$ for S. thermophilus or Gly $(1.5 \%)$ for Lc. lactis until the $\mathrm{OD}_{600}$ reached $0 \cdot 6-1$. Cells were collected by centrifugation at $5000 \mathrm{~g}$ for $5 \mathrm{~min}$ and washed four times in $0.5 \mathrm{M}$ sucrose $/ 10 \%$ glycerol solution.
They were then resuspended in 10\% glycerol $/ 30 \%$ PEG2000 solution for $S$. thermophilus or in $0.5 \mathrm{M}$ sucrose $/ 10 \%$ glycerol solution for Lc. lactis and immediately frozen in liquid $\mathrm{N}_{2}$ and stored at $-80{ }^{\circ} \mathrm{C}$.

DNA sequencing. The Sanger method of DNA sequencing was carried out on double-strand DNA plasmids and on PCR products with the BigDye Terminator cycle sequencing ready reaction kit (370A DNA sequencer, Applied Biosystems).

Construction of a negative mutant for PrtS. A 3776 bp PCR product containing part of the $p r t S$ gene was amplified using oligonucleotides 1 (5' CAT CAC GGA AAG TCT AGG 3') and 2 (5' AAC GTA TTG ATA CTT ACC $\left.3^{\prime}\right)$ from total DNA of $S$. thermophilus CNRZ 385 strain (Fig. 1). Streptococcal DNA (100 ng) was added to a PCR mixture containing $2.5 \mathrm{U}$ of Taq polymerase (Quantum Appligene) and $0.26 \mu \mathrm{M}$ of each oligonucleotide (Life Technology). After $5 \mathrm{~min}$ of denaturation at $94{ }^{\circ} \mathrm{C}, 30$ cycles of $30 \mathrm{~s}$ annealing at $50{ }^{\circ} \mathrm{C}$ and $3 \mathrm{~min}$ of elongation at $72^{\circ} \mathrm{C}$ were carried out using a Perkin-Elmer DNA thermal cycler (model 480). The amplified fragment was purified from $0.7 \%$ agarose gel with the QIAquick gelextraction kit (Qiagen). It was then ligated to pCR-XL-TOPO vector (Invitrogen) and cloned by transformation of electrocompetent TOP10 E. coli cells (Invitrogen) according to the manufacturer's protocol. The recombinant vector, pCR-XLTOPO- $\Delta p r t S-1$, was purified with QIAprep Spin Miniprep Kit (Qiagen) from the recombinant cells and digested with BsgI (New England Biolabs). A $5.4 \mathrm{~kb}$ fragment containing the 
TopoXL vector and part of the prtS gene was then purified from $0.7 \%$ agarose gel with QIAquick gel extraction kit (Qiagen) and blunt-ended with T4 polymerase $3^{\prime} \rightarrow 5^{\prime}$ exonuclease (Life Technologies) according to the supplier's protocol. It was then circularized by self-ligation with Fast-link DNA ligation kit (Epicentre Technology); the resulting plasmid, pCR ${ }^{\circledR}$-XL-TOPO- $\Delta p r t S-2$, was produced by transformation of electrocompetent TOP10 E. coli cells and purified as described above. It was then digested with NotI and SpeI (Eurogentec), and the resulting 2.078 kb fragment was purified as already described above. The $2.078 \mathrm{~kb}$ fragment ( $\sim 200 \mathrm{ng}$ ) was ligated to pGhost9 vector ( $100 \mathrm{ng}$ ) (Maguin et al., 1996), digested with NotI and SpeI. The ligation mix was used to electrotransform $100 \mu \mathrm{l}$ of electrocompetent cells of $L c$. lactis MG1363, as described by Holo \& Nes (1989). Recombinant clones were selected on M17Lac Ery plates after incubation at $28{ }^{\circ} \mathrm{C}$. The recombinant vector, $\mathrm{pG}^{+} \mathrm{h} 9:: \Delta p r t S$, was purified as described above, and $20 \mu \mathrm{g}$ was used to transform electrocompetent cells of $S$. thermophilus CNRZ 385, as previously described (Garault et al., 2000). Integration of $\mathrm{pG}^{+} \mathrm{h} 9:: \Delta p r t S$ into the streptococcal chromosome was performed as described by Garault et al. (2000) with the following modification: to induce chromosomal integration of the plasmid, the culture was diluted and plated on M17Lac Ery plates. Finally, the mutant for PrtS was obtained by successive incubations of the culture containing the chromosomal integration at $37^{\circ} \mathrm{C}$ to favour the excision of the pGhost9 plasmid.

\section{RESULTS}

\section{PrtS is essential to $S$. thermophilus growth in milk}

S. thermophilus PrtS-negative mutant construction. We have described here for the first time the construction of a targeted negative mutant for $S$. thermophilus cell-wall proteinase PrtS. This mutant of $S$. thermophilus CNRZ 385 was constructed by gene replacement using a truncated copy of $p r t S$ gene cloned in pGhost 9 plasmid. DNA sequencing confirmed that this copy was inserted at the $p r t S$ locus and that pGhost9 was subsequently excised, resulting in a truncated $p r t S$ gene. As expected, the truncated gene was deprived of part of the signal sequence, all the pro-region (removed after maturation of the protein in the parental strain), and almost all of the region encoding the catalytic domain of the enzyme (Fig. 1). Only the region encoding the six C-terminal amino acids among the 495 constituting the catalytic domain (PR domain) was still present in the mutant and did not include the sequence encoding the residues involved in the catalytic activity of the proteinase (Fernandez-Espla et al., 2000). Furthermore, protein exportation signals were no longer present in the mutant; the signal sequence was truncated, and the expected peptide cleavage site was excised.

Cell-wall proteinase activity of the wild-type and PrtSnegative mutant of $\boldsymbol{S}$. thermophilus. Using two different methods, we checked that the S. thermophilus PrtSnegative mutant lacked cell-wall proteinase activity. First, using ${ }^{14} \mathrm{C}$-labelled casein as a substrate, we observed that cell suspensions of the PrtS-positive strain were capable of hydrolysing casein $(12.5 \%$ of total casein hydrolysed within $10 \mathrm{~min})$, whereas PrtS-negative cells had no detectable caseinolytic activity. Second, we set up a rapid test on colonies using a chromogenic substrate of PrtS. Three strains of S. thermophilus were used: the proteinase-negative strain CNRZ 302 as negative control and the two proteinase-positive strains CNRZ 385 and CNRZ 703, which have a high cell-wall proteinase activity (Shahbal et al., 1991, 1993). After growing on milk agar plates, colonies were covered with a solution containing the substrate Suc-A-A-P-F- $\beta$ NA, Fast-Garnet and different concentrations of $\mathrm{CaCl}_{2}$, the latter being an activator of PrtS proteinase (FernandezEspla et al., 2000). Whatever the $\mathrm{CaCl}_{2}$ concentration $(10,20$ or $50 \mathrm{mM})$, colonies of strains 703 and 385 rapidly became red, whereas those of the negative strain 302 remained white. Using this test, we confirmed that the mutant strain was PrtS-negative, as colonies remained white even after several hours of contact with the substrate solution. This test functioned on milk plates but not on rich medium M17 plates for strain 703, which confirmed a probable regulation of prtS expression by the growth medium as already observed for this strain (Shahbal et al., 1993). This test will be useful to screen for $S$. thermophilus PrtS-negative strains in milk and also for PrtS-deregulated strains in M17.

Growth characteristics of the wild-type and PrtS-negative mutant of S. thermophilus. By comparing the phenotypes of the parental strain 385 and its PrtS $^{-}$mutant on FSDA, and their growth curves in liquid M17 and milk, we showed that proteinase PrtS was essential to the growth of $S$. thermophilus in milk.

The PrtS- mutant, plated on FSDA, appeared as flat and translucent colonies, as expected for $\mathrm{PrtS}^{-}$bacteria, whereas the $\operatorname{PrtS}^{+}$parental strain appeared as white, opaque, rounded colonies.

In M17, both strains had similar growth curves with a $\mu_{\max }$ of 0.89 and $0.85 \mathrm{~h}^{-1}$ for the parental strain and the mutant strain, respectively. In milk, streptococcal growth was determined indirectly by $\mathrm{pH}$ measurement. Growth of the $\mathrm{PrtS}^{-}$mutant was severely impaired in milk, as indicated by the reduced acidification of milk by this strain compared to the parental strain 385 (Fig. 2). For the $\mathrm{PrtS}^{-}$strain, milk acidification, and thus bacterial growth, was restored to the same extent as that for the wild-type strain, after the addition of yeast extract to milk (Fig. 2).

\section{The Lactobacillus strain influences the extent of the positive effect of $S$. thermophilus/Lb. bulgaricus association}

Mixed cultures of $S$. thermophilus and Lb. bulgaricus were made using two different strains of Lb. bulgaricus. To choose the last two strains, we first determined the effect of the co-culture of $L b$. bulgaricus strains with the S. thermophilus CNRZ385 strain on milk acidification, compared to the pure culture of Lb. bulgaricus (Fig. 3). Among the three strains of lactobacilli tested, the effect of adding strain 385 on the acidification was greatest with strains Lb. bulgaricus 397 and 1038; indeed, for these two Lactobacillus strains, the addition of the Streptococcus highly enhanced the acidification rate 


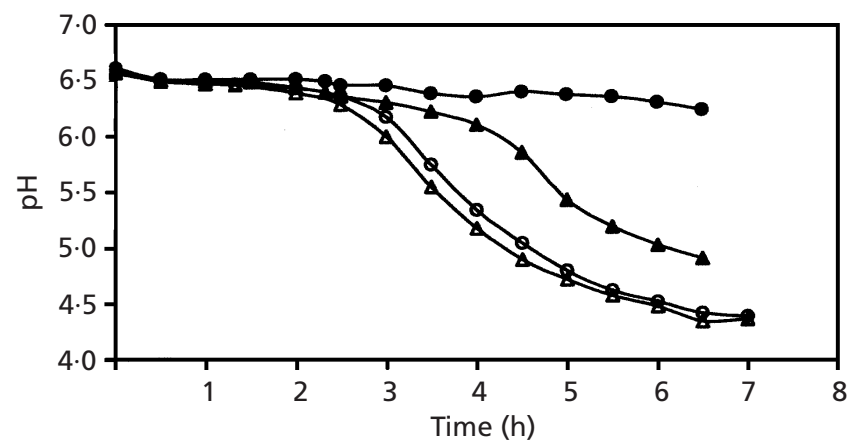

Fig. 2. Acidification curves of $\mathrm{PrtS}^{+} S$. thermophilus strain $385(\boldsymbol{\Delta}, \triangle)$ and its PrtS mutant grown in milk $(0,0)$, in the presence $(O, \triangle)$ or absence $(\boldsymbol{O}, \boldsymbol{\Delta})$ of yeast extract.

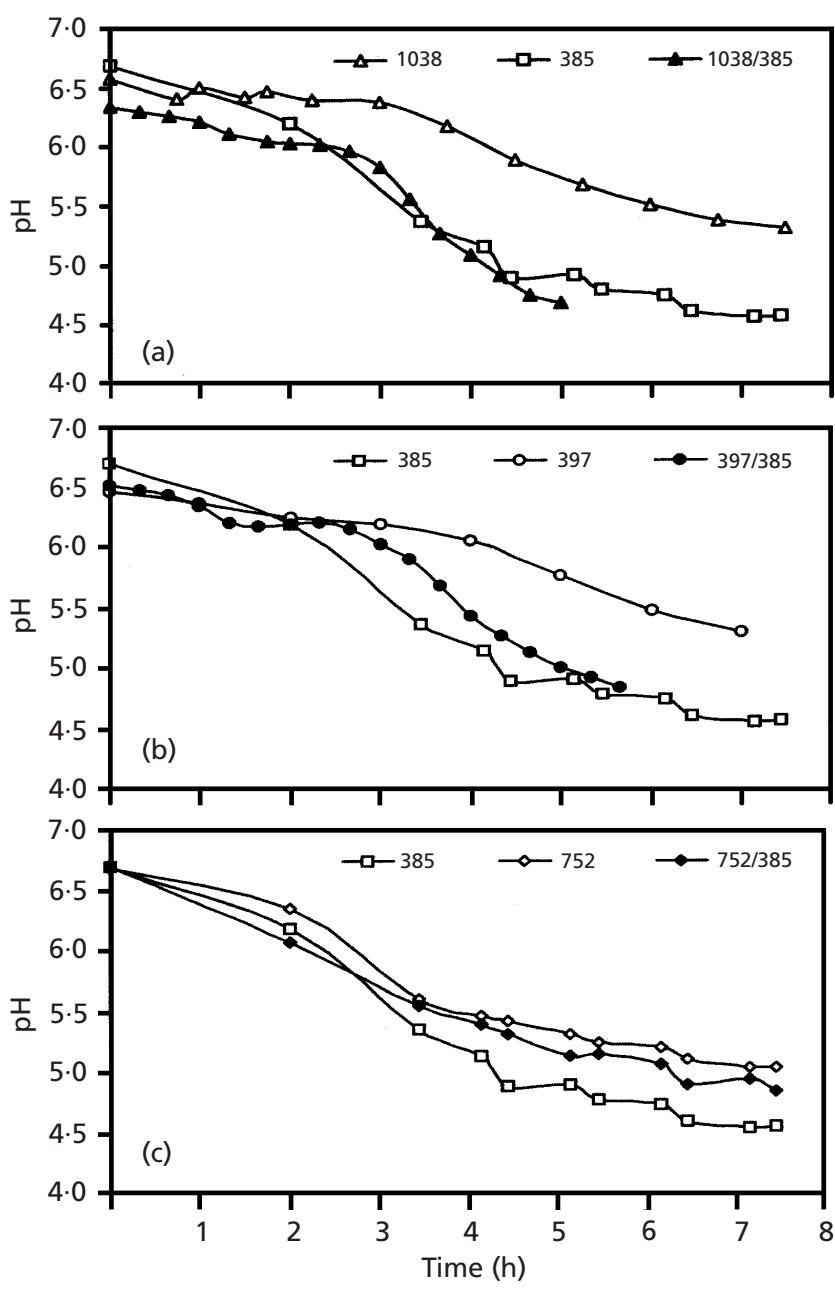

Fig. 3. Milk acidification curves of $S$. thermophilus 385 , and $L b$. bulgaricus (1038) (a), 397 (b) and 752 (c) in the presence or absence of $S$. thermophilus 385.

compared to the Lb. bulgaricus strain alone (Fig. 3a, b). Furthermore, the positive effect of the bacterial association on milk acidification was more intense for strain 1038, as, for this strain, the acidification rate and the final $\mathrm{pH}$ were higher and lower, respectively, in the mixed culture than in the pure culture. In contrast, addition of $S$. thermophilus strain 385 had no significant effect on milk acidification by Lb. bulgaricus strain 752
(Fig. 3c). Thus, strains 397 and 1038 of Lactobacillus were kept for the following study. In addition, a proteinase-negative mutant of strain Lb. bulgaricus CNRZ 397 was available and was used for the following experiments.

\section{In mixed cultures, proteinase PrtS has no effect on final $\mathrm{pH}$ and bacterial populations, but PrtB affects both}

The effect of proteinases PrtS and PrtB on acidification of mixed cultures and bacterial populations was estimated by measuring the final $\mathrm{pHs}$, final total bacterial populations and final individual populations of cultures performed with a strain of $S$. thermophilus $\operatorname{PrtS}^{+}$(strain 385) or $\mathrm{PrtS}^{-}$(strain 385-PrtS) and a strain of $L b$. bulgaricus $\mathrm{PrtB}^{+}$(strains 397 and 1038) or $\operatorname{PrtB}^{-}$(strain 397-PrtB).

The presence of proteinase PrtS had no effect either on the final bacterial populations or on the final $\mathrm{pHs}$ of mixed cultures involving $\operatorname{PrtB}^{+}$Lactobacillus strains. The final total populations were always similar in the presence or not of proteinase PrtS: 1.39 and $1.36 \times 10^{9}$ c.f.u. $\mathrm{ml}^{-1}$, respectively, for cultures involving $L b$. bulgaricus strain 1038 , and $7 \cdot 05$ and $6.27 \times 10^{8}$ c.f.u. $\mathrm{ml}^{-1}$, respectively, with strain 397 . The absence of any differences in final total populations corresponded to similar final individual populations of $S$. thermophilus and $L b$. bulgaricus, regardless of the presence of PrtS: $1.3 \times 10^{9}$ c.f.u. $\mathrm{ml}^{-1}$ for strains 385 and 385 -PrtS and $8.9 \times 10^{7}$ c.f.u. $\mathrm{ml}^{-1}$ for strain 1038 for mixed cultures involving strain $1038,5 \cdot 5 \times 10^{8}$ c.f.u. $\mathrm{ml}^{-1}$ for strains 385 and 385 -PrtS and $1 \cdot 1 \times 10^{8}$ c.f.u. $\mathrm{ml}^{-1}$ for strain 397 in mixed cultures involving strain 397 . This correlated well with the similar final $\mathrm{pH}$ obtained: 4.72 and 4.85 for mixed cultures involving, respectively, strain 1038 and strain 397.

It is noteworthy that both the final total bacterial populations and the acidification rates varied according to the Lactobacillus strain associated with $S$. thermophilus strain 385 . The final total population when using Lactobacillus strain $1038\left(1.38 \times 10^{9}\right.$ c.f.u. $\left.\mathrm{ml}^{-1}\right)$ was twice as high as that of strain $397\left(6.67 \times 10^{8}\right.$ c.f.u. $\left.\mathrm{ml}^{-1}\right)$, because the Streptococcus populations were more than twice as high with strain 1038, Lactobacillus populations remaining constant. Final $\mathrm{pHs}$ were not significantly different, but the time required to reach these $\mathrm{pHs}$ was 

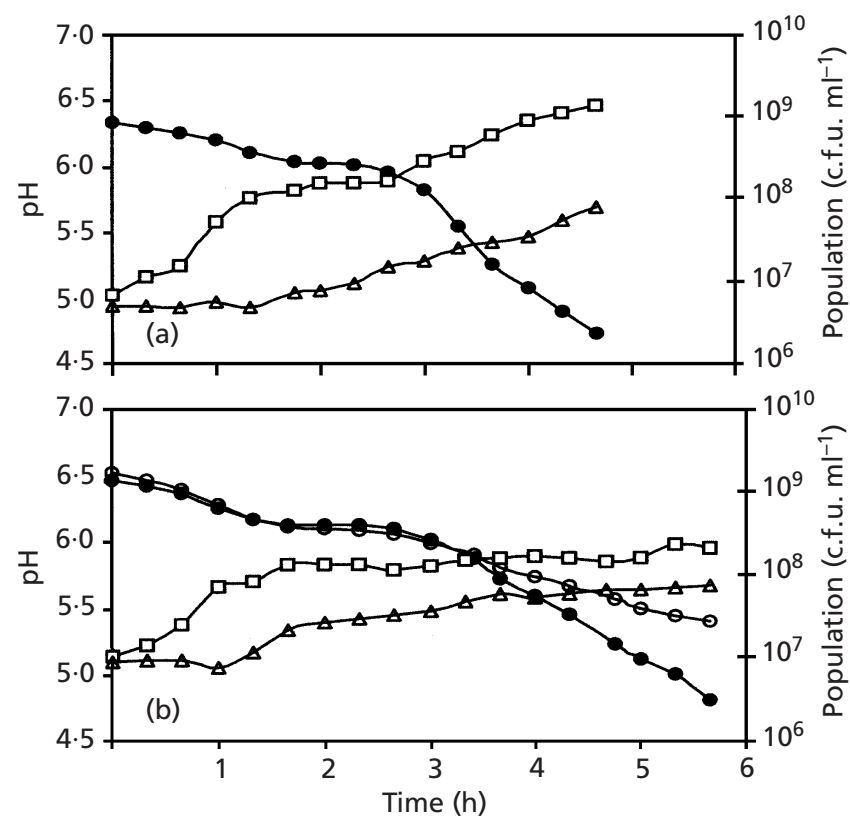

Fig. 4. Variation of $\mathrm{pH}$ and specific bacterial populations during mixed cultures in milk of $S$. thermophilus and Lb. bulgaricus. (a) Mixed culture 385/1038: ๑, $\mathrm{pH} ; \triangle$, population of $1038 ; \square$, population of 385 . (b) Mixed cultures 385/397 and 385/397-PrtB: 0, $\mathrm{pH}$ of culture $385 / 397 ; \mathrm{O}, \mathrm{pH}$ of culture 385/397-PrtB; $\square$, population of 385 in mixed culture 385/397-PrtB; $\triangle$, population of 397PrtB in mixed culture 385/397-PrtB. shorter for mixed cultures, including strain 1038, than those including strain 397 (4.66 h with strain 1038 versus $5 \cdot 66$ h with strain 397).

In contrast, the presence of proteinase PrtB affected both the final bacterial populations and the final pHs. Final total bacterial populations were threefold higher in the presence of PrtB than in its absence $\left(7.05 \times 10^{8}\right.$ versus $2 \cdot 8 \times 10^{8}$ c.f.u. $\mathrm{ml}^{-1}$ ). This resulted from higher final populations of $S$. thermophilus in the presence of $\operatorname{PrtB}$ $\left(6 \cdot 1 \times 10^{8}\right.$ versus $2.06 \times 10^{8}$ c.f.u. $\left.\mathrm{ml}^{-1}\right)$ and led to a significantly better acidification in the presence of $\operatorname{PrtB}$ (final $\mathrm{pH} 4.86$ versus $5 \cdot 42$ ).

In our conditions of inoculation (Streptococcus/Lactobacillus ratio of $1: 1$ ), S. thermophilus was systematically predominant in the total final populations, regardless of the strain of Lactobacillus and the presence of proteinases PrtS and PrtB. The magnitude of this predominance depended on the Lb. bulgaricus strain used: with strain 1038, S. thermophilus populations were 15 fold higher than Lactobacillus populations and fivefold higher with strain 397, when PrtB was present. This predominance was less marked in the absence of PrtB, as the $S$. thermophilus populations were threefold lower $\left(6 \cdot 1 \times 10^{8}\right.$ c.f.u. $\left.\mathrm{ml}^{-1}\right)$ than populations reached in the presence of $\operatorname{PrtB}\left(2 \cdot 06 \times 10^{8}\right.$ c.f.u. $\left.\mathrm{ml}^{-1}\right)$.

\section{Variation of individual populations of $S$. thermophilus and $L b$. bulgaricus throughout mixed cultures in milk}

Proteinase PrtS had no significant effect on the variation of $\mathrm{pH}$ and of individual populations throughout the culture and, regardless of the mixed culture considered (except that involving strain $\operatorname{PrtB}^{-}$), the variation of these two parameters remained similar. Fig. 4a gives an example of this variation (a mixed culture made of $S$. thermophilus 385 and Lb. bulgaricus 1038); for mixed cultures including Lb. bulgaricus strain 397, we observed the same behaviour (data not shown). During the first 60-90 min, which corresponded to the first acidification phase, $S$. thermophilus grew exponentially, whereas $L b$. bulgaricus did not grow significantly. Then, as the $\mathrm{pH}$ remained constant, the streptococcal population stabilized for about 60-90 min, whereas Lb. bulgaricus started to grow regularly and continuously. Finally, during the last 2 or $3 \mathrm{~h}$ of fermentation, when the acidification rate was the highest, both the Lactobacillus and the Streptococcus grew regularly.

In contrast, proteinase PrtB was clearly involved in the variation of bacterial populations and of $\mathrm{pH}$, as demonstrated with mixed cultures involving strain 397-PrtB (Fig. 4b). In fact, regardless of the presence of PrtB, the first two phases of acidification corresponding to the sequential growth of $S$. thermophilus and Lb. bulgaricus were similar. However, during the third acidification phase, the growth of $S$. thermophilus slowed down in the absence of PrtB, the bacterial populations remaining almost constant during the last $2 \mathrm{~h}$ of fermentation. This reduced growth resulted in a reduced acidification rate and an increased final $\mathrm{pH}(\mathrm{pH} 5.42$ in the absence of PrtB and 4.86 in the presence of $\operatorname{PrtB})$.

\section{DISCUSSION}

The present work aimed at evaluating the role of proteinase PrtS from S. thermophilus in the growth in milk of $S$. thermophilus in a pure culture. We also determined the effect of the presence of both PrtS and $\operatorname{PrtB}$ from $L b$. bulgaricus on $S$. thermophilus $/ L b$. bulgaricus mixed cultures. For this purpose, we constructed a targeted negative mutant of proteinase PrtS from $S$. thermophilus CNRZ 385 and performed pure cultures of $S$. thermophilus and mixed cultures with $L b$. bulgaricus in milk. 
In milk, the extent of the beneficial effect of the $S$. thermophilus/Lb. bulgaricus association varies

We observed that the effect of the co-culture of $L b$. bulgaricus strains with $S$. thermophilus strain 385 on the acidification of milk, and thus the benefit of the bacterial association, depends on the strain of Lb. bulgaricus used. In fact, with $L b$. bulgaricus strain 752, we did not obtain a marked beneficial effect of the association with S. thermophilus 385 as already observed by several authors with other strains (Accolas et al., 1977; Bautista et al., 1966; Sodini et al., 2000). In contrast, mixed cultures of strains 1038 and 397 resulted in a higher acidification than pure cultures. Acidification was higher with strain 1038 than with strain 397 due to higher $S$. thermophilus populations, Lb. bulgaricus populations being similar. These higher $S$. thermophilus populations probably resulted from a better peptide and/or amino acid supply by one Lactobacillus strain compared to the other as these nitrogen compounds are growth-limiting for $S$. thermophilus in milk. The two strains of $L b$. bulgaricus thus probably differ in their proteolytic potential, which is in agreement with the differences observed in the final quantities of free amino acids and free $\mathrm{NH}_{2}$ groups in the supernatants of mixed cultures including these two strains (data not shown). Some authors have also reported a variability in the $L b$. bulgaricus proteolytic potential (El-Soda et al., 1986; Rajagopal \& Sandine, 1990; Singh \& Sharma, 1983). This variability could be related to the presence of one cell-wall proteinase in Lb. bulgaricus, which is the case of strain 397 (Gilbert et al., 1997), or of two proteinases, as reported for other strains (Pederson et al., 1999; Stefanisti et al., 1995).

\section{PrtS is essential to the growth of S. thermophilus in milk in pure culture but not in mixed culture}

Proteinase PrtS is essential to the growth of $S$. thermophilus growth in milk as its $\mathrm{PrtS}^{-}$mutant was unable to grow efficiently in milk until a nutritional complement [yeast extract or bactotryptone (data not shown)] was added. This indicated that proteinase PrtS was involved in nitrogen supply to the cell, via casein hydrolysis, which is consistent with data previously obtained with cell-wall proteinases of other lactic acid bacteria (Exterkate, 1990; Gilbert et al., 1997; Thomas \& Pritchard, 1987).

However, we demonstrated here that proteinase PrtS had no significant effect on the growth of $S$. thermophilus in mixed cultures in milk with Lb. bulgaricus; the growth of the parental strain 385 and of the $\operatorname{PrtS}^{-}$ mutant in mixed culture was similar when Lb. bulgaricus proteinase PrtB was present. This indicates that assimilable nitrogen compounds necessary for $S$. thermophilus growth are supplied by PrtB, as confirmed by the fact that the absence of PrtB led to lower streptococcal populations. Furthermore, as the streptococcal population was higher in the presence of $\operatorname{PrtB}$ than in the presence of PrtS, we can assume that PrtB is more efficient in the supply of peptides to S. thermophilus than PrtS. This can be explained by a more active proteinase PrtB compared to PrtS, as previous studies reported that the global proteolytic activities of $L b$. bulgaricus strains were 25-70 times higher than that of S. thermophilus strains (Rajagopal \& Sandine, 1990; Shankar \& Davies, 1978). We cannot rule out the possibility that $\operatorname{PrtS}$ and $\operatorname{PrtB}$ have different substrate specificity, which leads to the production of different peptides, some being more assimilable than others. Indeed, PrtS is capable of hydrolysing MS-Arg-Pro-TyrpNA (Fernandez-Espla et al., 2000), a substrate also hydrolysed by lactococcal proteinase PrtP (Exterkate, 1990) but not by PrtB (Laloi et al., 1991). Furthermore, when comparing the substrate-binding region of proteinases PrtS and PrtB, in particular the residues 138, 166,748 , which have been identified as being directly involved in substrate specificity in lactococci (Siezen et al., 1993), we noticed that they are totally different in PrtS (Thr, Ala, Asp) (Fernandez-Espla et al., 2000) and PrtB (Gly, Val, Thr) (Gilbert et al., 1996).

\section{Model of growth of $S$. thermophilus associated with $L b$. bulgaricus and effect on acidification}

In all the mixed cultures performed in milk, we observed the sequential development of $S$. thermophilus and then of $L b$. bulgaricus, which is in agreement with previous studies (Beal \& Corrieu, 1991; Pette \& Lolkema, 1950a; Puhan \& Banhegyi, 1974; Tamine \& Robinson, 1999). Recently, the growth of $S$. thermophilus in pure culture in milk has been characterized, in particular with regard to nitrogen nutrition (Letort et al., 2002); it consists of two exponential growth phases, interrupted by a non-exponential growth phase. From these latter results and those of the present work, we propose the following model of growth of $S$. thermophilus in mixed cultures with Lb. bulgaricus with three S. thermophilus growth phases corresponding to three acidification steps.

During the first acidification step, characterized by a small decrease in $\mathrm{pH}(<0.5 \mathrm{pH}$ units), S. thermophilus grows exponentially, whereas $L b$. bulgaricus does not grow; $S$. thermophilus is thus responsible for this first acidification, as first observed by Pette \& Lolkema (1950c). The preferential growth of $S$. thermophilus can be explained first by the fact that $S$. thermophilus has fewer nutritional requirements than lactobacilli in milk (Desmazeaud, 1983). In particular, S. thermophilus requires few amino acids and is capable of synthesizing branched-chain amino acids (Garault et al., 2000); its growth can probably be supported by free amino acids and peptides present in milk, as previously demonstrated in pure culture, regardless of the presence of PrtS (Letort et al., 2002). In contrast, Lb. bulgaricus is much more demanding from a nutritional point of view than $S$. thermophilus (Letort, 2001); its optimal growth relies on the supply of essential factors $\left(\mathrm{CO}_{2}\right.$, pyruvate, formate) produced by $S$. thermophilus (for reviews, see Tamine \& Robinson, 1999; Zourari et al., 1992). Second, in our study, mixed cultures were performed at 
$42^{\circ} \mathrm{C}$, a temperature more favourable for $S$. thermophilus, whose optimal growth temperature ranges between 40 and $45^{\circ} \mathrm{C}$, versus $45-50^{\circ} \mathrm{C}$ for Lb. bulgaricus.

Then, the $S$. thermophilus exponential growth pauses and, concomitantly, the acidification, while $L b$. bulgaricus begins to grow slowly and regularly until the end of fermentation. This pause probably corresponds to depletion of amino acids and peptides in milk, due to their consumption by $S$. thermophilus, as shown recently by Letort et al. (2002) in pure culture, and the absence of compensatory production by cell-wall proteinases. These authors actually demonstrated that proteinase PrtS synthesis starts in the middle of this phase and is maximal during the second exponential growth phase in pure culture. Concerning the growth of Lb. bulgaricus, we assume that as $S$. thermophilus reaches a high cellular density during its first growth phase, it probably produces enough growth-stimulating factors to favour the growth of Lb. bulgaricus.

Finally, during the following acidification phase, which leads to a high $\mathrm{pH}$ decrease (about $1.5 \mathrm{pH}$ units), $L b$. bulgaricus continues to grow; at the same time, $S$. thermophilus starts a second exponential growth phase. We suggest that this acidification results not only from the growth of $L b$. bulgaricus but also from that of $S$. thermophilus. This acidification phase is indeed greatly improved by the addition of $S$. thermophilus to a $L b$. bulgaricus culture; furthermore, in the absence of PrtB, acidification is reduced, while only $S$. thermophilus populations significantly decrease. The growth of $S$. thermophilus probably occurs because of the utilization of peptides produced by PrtS (when PrtB is absent) but also mainly by PrtB. No differences in the growth of $S$. thermophilus were observed in the presence or absence of PrtS when PrtB was present, and S. thermophilus populations were significantly reduced in the absence of PrtB, i.e. when PrtS was the sole source of peptide production.

In conclusion, we have determined the role of cell-wall proteinases PrtS and PrtB in the growth of S. thermophilus and Lb. bulgaricus in mixed cultures. We have shown that PrtB is involved in the optimal growth of $S$. thermophilus, whereas PrtS does not play a significant role when PrtB is present. Studies of the effect of these proteinases on the free amino acid and peptide contents as well as on the aroma profiles of mixed cultures are in progress. As precursors, amino acids are involved in the formation of aroma in dairy products, and variations in their composition can affect aroma development. However, the different $\mathrm{pH}$ values observed in the present study at the end of fermentation, when varying the presence of proteinase PrtB, can modify the yoghurt flavour (Ott et al., 2000).

\section{ACKNOWLEDGEMENTS}

We gratefully acknowledge D. Atlan and M. van de Guchte for the supply of Lb. bulgaricus strains 1159 and 1038, respectively. We thank $M$. Nardi, for her helpful suggestions concerning mutant construction, and $M$. Diard for his technical assistance.

\section{REFERENCES}

Accolas, J. P., Veaux, M. \& Auclair, J. (1971). Etude des interactions entre diverses bactéries lactiques thermophiles et mésophiles, en relation avec la fabrication des fromages à pâté cuite. Lait Accolas, J. P., Bloquel, R., Didienne, R. E Regnier, J. (1977). Propriétés acidifiantes des bacteries lactiques thermophiles en relation avec la fabrication du yoghourt. Lait 57, 1-23. 505-506, 249-272.

Bautista, E. S., Dahiya, R. S. \& Speck, M. L. (1966). Identification of compounds causing symbiotic growth of Streptococcus thermophilus and Lactobacillus bulgaricus in milk. J Dairy Res 33, 299-307.

Beal, C. \& Corrieu, G. (1991). Influence of $\mathrm{pH}$, temperature, and inoculum composition on mixed cultures of Streptococcus thermophilus 404 and Lactobacillus 398. Biotechnol Bioeng 38, 90-98.

Bracquart, P. \& Lorient, D. (1977). Effet des acides aminés sur la croissance de Streptococcus thermophilus. Milchwissenschaft 32, 221-224.

De Man, J. C., Rogosa, M. \& Sharpe, M. E. (1960). A medium for the cultivation of lactobacilli. J Appl Bacteriol 23, 130-135.

Desmazeaud, M. (1983). L'état des connaissances en matière de nutrition des bactéries lactiques. Lait 63, 267-316.

El-Soda, M. A., Desmazeaud, M. J., Le Bars, D. \& Zevaco, C. (1986). Cell-wall-associated proteinases in Lactobacillus casei and Lactobacillus plantarum. J Food Prot 49, 361-365.

Exterkate, F. A. (1990). Differences in short peptide-substrate cleavage by two cell-envelope-located serine proteinases of Lactococcus lactis subsp. cremoris are related to secondary binding specificity. Appl Microbiol Biotechnol 33, 401-406.

Fernandez-Espla, M.-D., Garault, P., Monnet, V. \& Rul, F. (2000). Streptococcus thermophilus cell wall-anchored proteinase, release, purification, and biochemical and genetic characterization. Appl Environ Microbiol 66, 4772-4778.

Garault, P., Letort, C., Juillard, V. \& Monnet, V. (2000). Branchedchain amino acid biosynthesis is essential for optimal growth of Streptococcus thermophilus in milk. Appl Environ Microbiol 66, 5128-5133.

Gasson, M. J. (1983). Plasmid complements of Streptococcus lactis NCDO 712 and other lactic streptococci after protoplastinduced curing. J Bacteriol 154, 1-9.

Gilbert, C., Atlan, D., Blanc, B., Portalier, R., Germond, J. E., Lapierre, L. \& Mollet, B. (1996). A new cell surface proteinase, sequencing and analysis of the prtB gene from Lactobacillus delbrueckii subsp. bulgaricus. J Bacteriol 178, 3059-3065.

Gilbert, C., Blanc, B., Frot-Coutaz, J., Portalier, R. \& Atlan, D. (1997). Comparison of cell surface proteinase activities within the Lactobacillus genus. J Dairy Res 64, 561-571.

Hamdy, M. K., Harper, W. J. \& Weisier, H. H. (1955). Acidic free amino compounds formed in various lactic acid starter cultures as measured by ion exchange chromatography. Appl Microbiol 3, 221-226.

Hebert, E. M., Raya, R. R. \& De Giori, G. S. (2000). Nutritional requirements and nitrogen-dependent regulation of proteinase activity of Lactobacillus helveticus CRL 1062. Appl Environ Microbiol 66, 5316-5321.

Hickey, M. W., Hillier, A. J. \& Jago, G. R. (1983). Peptidase activities in lactobacilli. Aust J Dairy Technol 38, 118-123. 
Higashio, K., Yoshioka, Y. \& Kikuchi, T. (1977). Isolation and identification of growth factor of Streptococcus thermophilus by Lactobacillus bulgaricus. J Agric Chem Soc Jpn 51, 203-208.

Holo, H. \& Nes, I. F. (1989). High-frequency transformation, by electroporation, of Lactococcus lactis subsp. cremoris grown with glycine in osmotically stabilized media. Appl Environ Microbiol 55, 3119-3123.

Huggins, A. M. \& Sandine, W. E. (1984). Differentiation of fast and slow milk coagulating isolates in strains of streptococci. J Dairy Sci 67, 1674-1679.

Laloi, P., Atlan, D., Blanc, B., Gilbert, C. \& Portalier, R. (1991). Cellwall-associated proteinase of Lactobacillus delbrueckii subsp. bulgaricus CNRZ 397, differential extraction, purification and properties of the enzyme. Appl Microbiol Biotechnol 36, 196-204.

Ledesma, O. V., de Ruiz Holgado, A. P., Oliver, G., de Giorgi, G. S., Raibaud, P. \& Galpin, J. V. (1977). A synthetic medium for comparative nutritional studies of lactobacilli. J Appl Bacteriol 42, 123-133.

Letort, C. (2001). Relation entre croissance et nutrition azotée de deux bactéries lactiques thermophiles, Streptococcus thermophilus et Lactobacillus delbrueckii subsp. bulgaricus. PhD thesis, University of Poitiers, France.

Letort, C. \& Juillard, V. (2001). Development of a minimal chemical defined medium for the exponential growth of Streptococcus thermophilus. J Appl Microbiol 91, 1-7.

Letort, C., Nardi, M., Garault, P., Monnet, V. \& Juillard, V. (2002). Casein utilization by Streptococcus thermophilus results in a diauxic growth in milk. Appl Environ Microbiol 68, 3162-3165.

Maguin, E., Prevost, H., Ehrlich, D. \& Gruss, A. (1996). Efficient insertional mutagenesis in lactococci and other Gram-positive bacteria. J Bacteriol 178, 931-935.

Monnet, V., Le Bars, D. \& Gripon, J. C. (1987). Partial characterization and comparison of cell wall proteinases from 5 strains of Streptococcus lactis. Lait 67, 51-61.

Morishita, T., Deguchi, Y., Yajima, M., Sakurai, T. \& Yura, T. (1981). Multiple nutritional requirements of lactobacilli, genetic lesions affecting amino acid biosynthetic pathways. J Bacteriol 148, 64-71.

Ott, A., Hugi, A., Baumgartner, M. \& Chaintreau, A. (2000). Sensory investigation of yogurt flavour perception, mutual influence of volatiles and acidity. J Agric Food Chem 48, 441-450.

Pederson, J. A., Mileski, G. J., Weimer, B. C. \& Steele, J. L. (1999). Genetic characterization of a cell envelope-associated proteinase from Lactobacillus helveticus CNRZ32. J Bacteriol 181, 45924597.

Pette, J. W. \& Lolkema, H. (1950a). Symbiosis and antibiosis in mixed cultures Lb. bulgaricus and S. thermophilus. Neth Milk Dairy J 4, 197-208.

Pette, J. W. \& Lolkema, H. (1950b). Growth stimulating factors for Streptococcus thermophilus. Neth Milk Dairy J 4, 209-224.

Pette, J. W. \& Lolkema, H. (1950c). Acid formation and aroma formation in yoghurt. Neth Milk Dairy J 4, 261-273.

Pospiech, A. \& Neumann, B. (1995). A versatile quick-prep of genomic DNA from Gram-positive bacteria. Trends Genet 11, 217-218.
Puhan, Z. \& Banhegyi, M. (1974). Effect of incubation temperature on the ratio of Lactobacillus bulgaricus to Streptococcus thermophilus in yoghurt. Schweiz Milchwirtsch Forsch 3, 9-13.

Radke-Mitchell, L. \& Sandine, W. E. (1984). Associative growth and differential enumeration of Streptococcus thermophilus and Lactobacillus bulgaricus, a review. J Food Prot 47, 245-248.

Rajagopal, S. N. \& Sandine, W. E. (1990). Associative growth and proteolysis of Streptococcus thermophilus and Lactobacillus bulgaricus in skim milk. J Dairy Sci 73, 894-899.

Sambrook, J., Fritsch, E. F. \& Maniatis, T. (1989). Molecular Cloning: a Laboratory Manual, 2nd edn. Cold Spring Harbor, NY : Cold Spring Harbor Laboratory.

Shahbal, S., Hemme, D. \& Desmazeaud, M. (1991). High cell wallassociated proteinase activity of some Streptococcus thermophilus strains (H-strains) correlated with a high acidification rate in milk. Lait 71, 351-357.

Shahbal, S., Hemme, D. \& Renault, P. (1993). Characterization of a cell envelope-associated proteinase activity from Streptococcus thermophilus H-strains. Appl Environ Microbiol 59, 177-182.

Shankar, P. A. \& Davies, F. L. (1977). Associative bacterial growth in yoghurt starters; initial observations on stimulatory factors. J Soc Dairy Technol 30, 31-32.

Shankar, P. A. \& Davies, F. L. (1978). [Conference paper] XX International Dairy Congress, Paris, vol. E, pp. 467-468.

Siezen, R. J. (1999). Multi-domain, cell-envelope proteinases of lactic acid bacteria. Antonie van Leeuwenhoek 76, 139-155.

Siezen, R. J., Bruinenberg, P. G., Vos, P., Van Allen-Boerrigter, I. J., Nijhuis, M., Alting, A. C., Exterkate, F. A. \& De Vos, W. M. (1993). Engineering of the substrate-binding region of the subtilisin-like, cell envelope proteinase of Lactococcus lactis. Protein Eng 6, 927-937.

Singh, J. \& Sharma, D. K. (1983). Proteolytic breakdown of casein and its fraction by lactic acid bacteria. Milchwissenschaft 38, 148-149.

Sodini, I., Latrille, E. \& Corrieu, G. (2000). Identification of interacting mixed cultures of lactic acid bacteria by their exclusion from a model predicting the acidifying activity of non-interacting mixed cultures. Appl Microbiol Biotechnol 54, 715-718.

Stefanitsi, D., Sakellaris, G. \& Garel, J. R. (1995). The presence of two proteinases associated with the wall of Lactobacillus bulgaricus. FEMS Microbiol Lett 128, 53-58.

Tamine, A. Y. \& Robinson, R. K. (1999). Yoghurt Science and Technology, 2nd edn. Cambridge: Woodhead.

Terzaghi, B. E. \& Sandine, W. E. (1975). Improved medium for lactic streptococci and their bacteriophages. Appl Microbiol 29, 807-813.

Thomas, T. D. \& Mills, O. E. (1981). Proteolytic enzymes of starter bacteria. Neth Milk Dairy J 35, 255-273.

Thomas, T. D. \& Pritchard, G. G. (1987). Proteolytic enzymes of dairy starter cultures. FEMS Microbiol Rev 46, 245.

Zourari, A., Accolas, J. P. \& Desmazeaud, M. J. (1992). Metabolism and biochemical characteristics of yogurt bacteria. A review. Lait $72,1-34$.

Received 4 April 2002; revised 20 June 2002; accepted 15 July 2002. 